\title{
Vitality of job satisfaction in mediation: the effect of reward and personality on organizational commitment
}

\author{
Widodo Widodo $^{\mathbf{a}^{*}}$ and Ratih Damayanti ${ }^{\mathrm{b}}$
}

${ }^{a}$ Faculty of Education and Social Sciences of Indraprasta University, Jakarta, Indonesia

${ }^{b}$ Indonesia Television Academy, Jakarta, Indonesia

\section{H R O N I C L E}

\section{Article history:}

Received: October 15, 2019

Received in revised format: November 262019

Accepted: January 27, 2020

Available online:

January 27, 2020

Keywords:

Reward

Personality

Job satisfaction

Organizational commitment

\section{A B S T R A C T}

\begin{abstract}
The research explores the direct and indirect effects of reward, personality and job satisfaction on teacher's organizational commitment in Public Vocational High Schools in Bogor City, West Java, Indonesia. Data for this study was collected quantitatively through a survey, involving a proportionate randomly selected sample of 154 teachers, by using a questionnaire. Path analysis supported by descriptive statistics was employed to analyze the data. The results confirm that reward, personality and job satisfaction had significant direct effects on organizational commitment; reward and personality had significant direct effect on job satisfaction; reward and personality had significant indirect effects on organizational commitment by mediating job satisfaction. Therefore, a fit research model found about the effect of reward and personality on organizational commitment by mediating job satisfaction with research settings on vocational high school in Indonesia. This model cannot only be used as a reference by researchers and practitioners in developing models of organizational commitment that are in accordance with their respective conditions, but can also be further developed and expanded into studies and projects to develop organizational commitment which is more complex and comprehensive by adding variables and other relevant dimensions.
\end{abstract}

\section{Introduction}

The contribution of vocational high school graduates to national unemployment in 2017 has increased, from $11.11 \%$ (2016) to $11.41 \%$ (2017) (Indonesian Central Bureau of Statistics, 2018). This condition indicates an inadequate quality of graduates of vocational high school in Indonesia and requires strengthening the organizational commitment of teacher's vocational high school, since teachers are the main actors of learning activities in schools.

\subsection{Organizational commitment}

Organizational commitment is "the degree to which an employee identifies with the organization and wants to continue actively participating in it" (Newstrom, 2015: 236). Organizational commitment also reflects "the extend to which an individual indentifies with an organization and its goal" (Kreitner \& Kinicki, 2010: 166). Accordting to Mowdey, Porter and Steers as quoted by Slocum and Hellriegel (2007: 328), organizational commitment refers to "the strength of an employee's involvement in the organization and identificatoon with it". Strong organizational commitment can be characterized as a support of acceptance of the organization's goals and values; a willingness to exert consideracle effort on behalf of the organization; and a desire to remain with the organization. 


\subsection{Job satisfaction}

Organizational commitment, among others, is influenced by job satisfaction. Job satisfaction has a direct effect on organizational commitment, including among others conducted by David (2015), Nwokolo and Anyamene (2015), Getahun, Tefera and Burichew (2016), Wang (2016), Abebe and Markos (2016), Bangwal et al. (2017), Tiwari and Chamola (2017), Faridi, Baloch and Wajidi (2017), Talasaz, Saadoldin and Shakeri (2017), Culibrk et al. (2018), Yao, Qiu, and Wei (2019). Job satisfaction refers to "how people feel about their jobs and different aspects of their jobs, it is the extent to which people like (satisfaction) or dislike (dissatisfaction) their jobs)" (Spector, 1997: 2) and "a results of employees' perception of how well their job provides those things that are viewed as important" (Luthans, 2011: 141). Job satisfaction can be measured through dimensions: work itself, promotion, supervision, partners, leadership, working conditions, challenges, nature of work and communication (Spector, 1997; Nelson \& Quik, 2006; Hodgetts, in McKenna, 2006; Luthans, 2011). Thus, it can be hypothesized:

$\mathrm{H}_{1}$ : Job satisfaction has a direct effect on organizational commitment.

\subsection{Reward}

Organizational commitment is also influenced by reward. Several studies report that reward has a direct effect on organizational commitment, for example: Saqib et al. (2015), Yongmei and Jiankai (2015), Korir and Kipkebut (2016), Chelangat and Gachunga (2016), Mabaso and Dlamini, 2018). According to McKenna (2006: 608), "the reward system comprises the various organizational activities aimed at the allocation of compensation and benefits to employees in return for the effort and contributions they make to the achievement of organizational objectives." According to Vecchio (2006), motivational specialists often distinguish between extrensic and intrinsic rewards. Extrinsic rewards come from sources that are outside of, or external to, the individual, while intrinsic rewards may be more accurately characterized as self-administered (that is, arising from within the person). Examples of extrinsic rewards include pay, fringe benefits, promotions, and perquisites. Examples of intrinsic rewards are feelings of competence, accomplishment, responsibility, and personal growth. Intrinsic compensation also reflects employees' psychological mind-sets that result from performing their jobs. Extrinsic compensation includes both monetary and non-monetary rewards. Monetary compensation represents core compensation, shows core compensation which includes: basic salary, seniority wages, service wages, incentive wages, wages for knowledge plans and skills based wages, and employee benefits. Nonmonetary rewards include protection programs (for example, medical insurance), paid time-off (for example, vacations), and services (for example, day care assistance). Most compensation professional refer to nonmonetary reward as employee benefits (Martocchio, 2006). Thus, it can be hypothesized:

$\mathrm{H}_{2}$ : Reward has a direct effect on organizational commitment.

\subsection{Personality}

Organizational commitment is also influenced by personality. The results of research by Shabahang and Amani (2016), Ziapour et al. (2017), Saufi et al. (2017), and Herath and Shamila (2018) show that personality has a direct effect on organizational commitment. Personality as the distinctive and relatively enduring ways of thinking, feeling, and acting that characterize a person's responses to a life situation throughout life (Passer \& Smith, 2007; Ciccarelli \& Meyer, 2006). Personality is also described as "distinctive thoughts, emotions, and behaviors that characteristics to motivate an individual adapt to the world" (Santrock, 2008: 135). Carver and Scheier (2008) identified six important things related to personality, which were: (1) personality is not just an accumulation of bits and pieces; it has organization; (2) personality does not just lie there; it has processes of some sort; (3) personality is a psychological concept; (4) personality is a causal force that helps determine how the person relates to the world; (5) personality shows up in individualized patterns-recurrences and consistencies; and (6) personality is displayed not just in one way but in many ways-in behaviors, thoughts, and feelings. Personality can be measured by The Big Five Dimensions of Personality, they are: (1) extraversion: a tendency to seek stimulation and to enjoy the company of other people. This reflects a dimension ranging from energetic, enthusiastic, sociable, and talkative at one end, to retiring, sober, reserved, silent, and cautious on the other; (2) agreeableness: a tendency to be compassionate toward others. This dimension ranges from good-natured, cooperative, trusting, and helpful at one end, to irritable, suspicious, and uncooperative at the other; (3) conscientiousness: a tendency to show self-discipline, to strive for competence and achievement. This dimension ranges from well organized, careful, self-disciplined, responsible, and precise at one end, to disorganized, impulsive, careless, and undependable at the other; (4) neuroticism: a tendency to experience unpleasant emotions easily. This dimension ranges from poised, calm, composed, and not hypochondriacal at one end, to nervous, anxious, high-strung, and hypochondriacal at the other; and (5) openness to experience: a tendency to enjoy new experiences and new ideas (Costa \& McCrae, 1992). Thus, it can be hypothesized:

$\mathrm{H}_{3}$ : Personality has a direct effect on organizational commitment. 
Job satisfaction in addition to influencing organizational commitment is also influenced by reward and personality. The results of research carried out by Jehanzeb et al. (2012), Munap, Badrillah and Rahman (2013), Bustamama, Tenga and Abdullahb (2014), and Akafo and Boateng (2015) showed that reward influences job satisfaction. Thus, it can be hypothesized:

$\mathrm{H}_{4}$ : Reward has a direct effect on job satisfaction.

Several studies conducted by Naz, Rehman and Saqib (2013), Balasuriya and Perera (2016), Ranasinghe and Kottawatta (2016), Bui (2017), and Ardakani, Heidari and Sefidgaran (2017) showed that personality influences job satisfaction. Thus, it can be hypothesized:

$\mathrm{H}_{5}$ : Personality has a direct effect on job satisfaction.

From the various results of the research above it can be seen that job satisfaction mediates the effect of reward and personality on organizational commitment, therefore it can be hypothesized:

$\mathrm{H}_{6}$ : Reward has an indirect effect on organizational commitment by mediating job satisfaction.

$\mathrm{H}_{7}$ : Personality has an indirect effect on organizational commitment by mediating job satisfaction.

\section{Research methods}

The sample of this study was 154 teachers taken by proportionate random sampling of 256 teachers of state vocational high schools in Bogor City, West Java, Indonesia based on the provisions in the Krejcie \& Morgan Table (1970). Data was collected by questionnaire in the form of a Likert scale model with five alternative answers: strongly disagree, disagree, neutral, agree and strongly agree. The questionnaire was made by researchers themselves based on the theoretical dimensions of the experts. Variable of organizational commitment uses three dimensions of Mowdey, Porter and Steers (in Slocum \& Hellriegel, 2007), namely: a support of acceptance of the organization's goals and values (AOG); a willingness to exert consideracle effort on behalf of the organization (WEO); and a desire to remain with the organization (being part of the organization) (DRO). Variable of job satisfaction uses dimensions work itself (WI), promotion (Pro), supervision (Sup), partners (Par), leadership (Lea), working conditions (WC), challenges (Cha), nature of work (NW) and communication (Com) (Spector, 1997; Nelson \& Quik, 2006; Hodgetts, in McKenna, 2006; Luthans, 2011). Variable of reward uses dimensions: pay, fringe benefits (FB), incentive (Inc), protection programs (PP), feelings of competence (FC), accomplishment (Acc), responsibility (Res), and personal growth (PG) (Vecchio, 2006; Martocciao, 2006). Variable of personality uses The Big Five Dimentions of Personality (Costa \& McCrae, 1992) which are: extraversion (Ext), agreeableness (Agr), conscientiousness (Con), neuroticism (Neu), and openness to experience (OE). Organizational commitment questionnaire consists of 26 items with alpha coefficient $=.898$, reward consists of 27 items with alpha coefficient $=.947$, personality consists of 27 items with alpha coefficient $=.946$, and job satisfaction consists of 25 items with alpha coefficient $=.931$. Data analysis using the Path Analysis and to test the significant of the path coefficient it uses t test.

\section{Research result}

The results of the descriptive statistical analysis for the four research variables are presented as followed:

Table 1

Descriptive statistics

\begin{tabular}{|c|c|c|c|c|c|}
\hline & & Reward & Personality & Job Satisfaction & Organizational Commitment \\
\hline \multirow[t]{2}{*}{$\mathrm{N}$} & Valid & 154 & 154 & 154 & 154 \\
\hline & Missing & 0 & 0 & 0 & 0 \\
\hline \multicolumn{2}{|c|}{ Mean } & 116.40 & 117.58 & 99.42 & 108.65 \\
\hline \multicolumn{2}{|c|}{ Median } & 117.00 & 117.00 & 100.00 & 109.00 \\
\hline \multicolumn{2}{|c|}{ Mode } & 124 & 115 & 101 & $109^{\mathrm{a}}$ \\
\hline \multicolumn{2}{|c|}{ Std. Deviation } & 7.208 & 5.979 & 10.393 & 9.011 \\
\hline \multicolumn{2}{|c|}{ Variance } & 51.955 & 35.749 & 108.022 & 81.197 \\
\hline \multicolumn{2}{|c|}{ Range } & 31 & 29 & 50 & 43 \\
\hline \multicolumn{2}{|c|}{ Minimum } & 100 & 104 & 75 & 87 \\
\hline \multicolumn{2}{|c|}{ Maximum } & 131 & 133 & 125 & 130 \\
\hline \multicolumn{2}{|c|}{ Sum } & 17926 & 18107 & 15310 & 16732 \\
\hline
\end{tabular}

a. Multiple modes exist. The smallest value is shown

As shown in Table 1, the mean values of the four variables from the lowest to the highest in succession are job satisfaction (99.42), organizational commitment (108.65), rewards (116.40) and personality (117.58). 


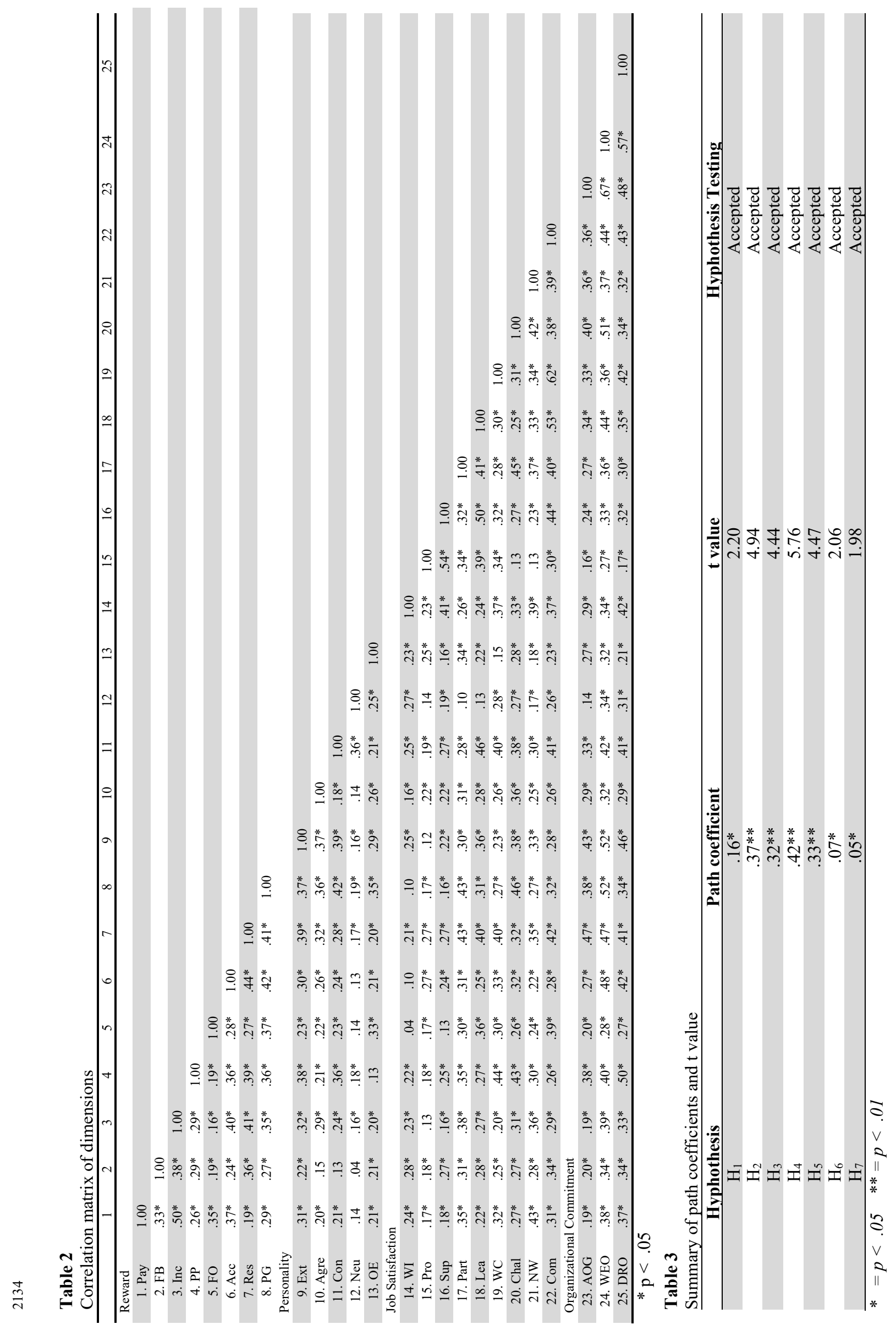


As shown in Table 2, most dimensions on each variable have significant relationships with the dimensions of the other variables at level $\mathrm{p}<.05$, except the relationship between pay and neu (.14); FB and agr (.15), con (.13), Neu (.04); Inc and Pro (.13); PP and OE (.13); FO and neu (.14), WI (.04), Spv (.13); Acc and Neu (.13), WI (.10); PG and WI (.10); Ext and Pro (.12); Neu and Pro (.14), par (.10), lea (.13), AOG (.14); OE and WC (.15). The results of hypothesis testing with path analysis of the effects of reward, personality, and job satisfaction on organizational commitment are summarized as followed:

The results of the path coefficient and t value can be described as followed:

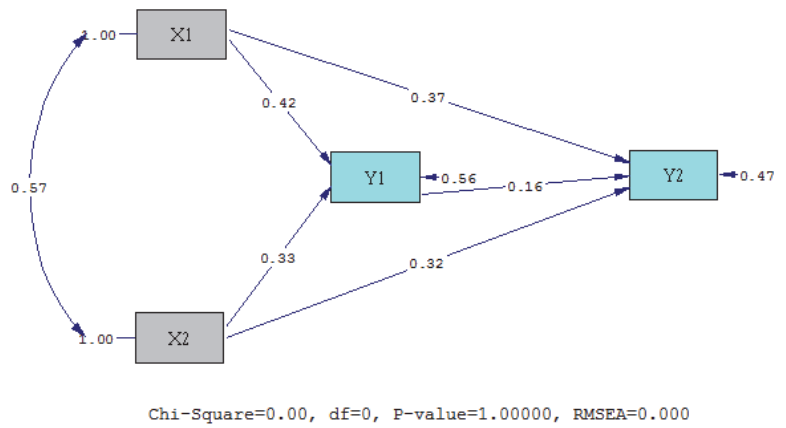

Fig. 1. Path Coefficient

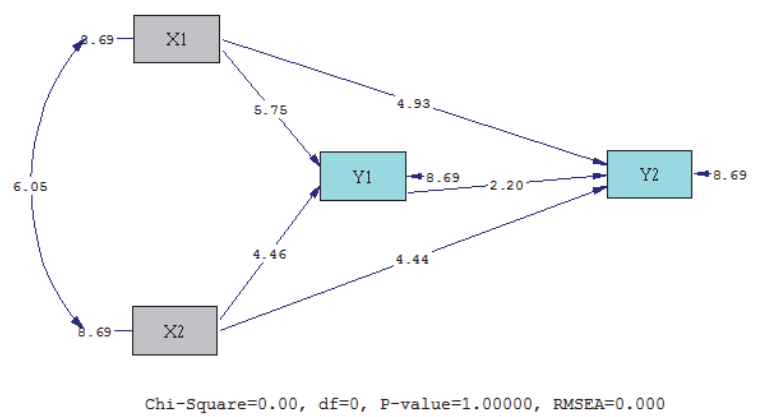

Fig. 2. T value

The test results in Table 3 show that all hypotheses were accepted. Reward, personality and job satisfaction had a significant direct effect on organizational commitment. Reward and personality had significant direct effects on job satisfaction. Reward and personality had significant indirect effects on organizational commitment by mediating job satisfaction. In Fig. 1 and Fig. 2 , the test results of the model with goodness of fit statistics show the significant or Chi-Square $=0.000, \mathrm{df}=0, \mathrm{p}$-value $=$ $1.00000>.05$ and RMSEA $=.000<.01$, so that the model tested is fit. That means the theoretical model being tested is supported by empirical data.

\section{Discussion}

\subsection{Direct Effect of Job Satisfaction on Organizational Commitment}

The results of this study have proven that job satisfaction had a positive and significant direct effect on organizational commitment. This indicates that the conditions of teacher's job satisfaction can have implications for teacher organizational commitment. Organizational commitment reflected in a sense of identification and involvement in the organization grows because the teacher gets what he expects from the organization. In this case, job satisfaction is one of the things that every teacher implicitly desires. Dissatisfied teachers tend to take negative actions that harm the organization, such as being lazy to work, frequent absence, switching to another job, disobeying organizational rules, and tend to work below the standards set. Meanwhile, teachers who are satisfied at work will tend to be diligent at work, orderly towards organizational rules and discipline. In addition, job satisfaction will also encourage teachers to remain loyal and not to have the desire to move to another place. The results of previous studies have also proven that job satisfaction have an influence on organizational commitment (e.g: Nwokolo \& Anyamene, 2015; Tefera \& Burichew, 2016; Talasaz, Saadoldin \& Shakeri, 2017; Ćulibrk et al., 2018; Yao, Qiu, $\&$ Wei, 2019). Thus, these findings are consistent, support and confirm the results of previous studies that job satisfaction has a positive and significant direct effect on organizational commitment with the setting of the teachers of state vocational high schools in Bogor City, West Java, Indonesia.

\subsection{Direct Effect of Reward on Organizational Commitment}

The results of this study also have shown that reward had a positive and significant direct effect on organizational commitment. This finding suggests that reward is still believed to be the main motivating factor for teachers to work. Moreover, if the reward is broadly interpreted which includes extrinsic and intrinsic reward, then the reward is very effective in building positive attitudes and behaviors of teachers at work, including to foster organizational commitment. If the teacher organization receives adequate financial reward, there are opportunities for self-growth and development of skills, and given sufficient responsibility, then it has become a logical consequence for these teachers to show a strong commitment to their organization. This finding confirms the results of previous studies on the effect of reward on organizational commitment by researchers in various countries and in various industrial and occupational sectors (e.g: Yongmei \& Jiankai, 2015; Saqib et al., 2015; Chelangat \& Gachunga, 2016; Korir \& Kipkebut, 2016; Mabaso \& Dlamini, 2018). Thus, these findings are consistent, support and confirm the results of previous studies that reward has a positive and significant direct effect on organizational commitment with the setting of the teachers of state vocational high schools in Bogor City, West Java, Indonesia. 
The results of this study also indicate that personality has a positive and significant direct effect on organizational commitment. This condition is inseparable from the characteristics of organizational commitment as individual internal variables which certainly intersect with other internal aspects, one of which is personality. In personality, there is a conscientiousness dimension that shows how far individuals want to work hard, orderly, trustworthy, and diligent. Such characteristics are an important foundation needed to build a strong commitment to the organization. Other personality dimensions such as extraversion, agreeableness, neuroticism, and openness to experience can also contribute to growing organizational commitment. This finding is as rigorous and confirms the results of previous studies that personality has a significant effect on organizational commitment (e.g: Shabahang \& Amani 2016; Ziapour et al., 2017; Abdullah, Saufi et al., 2017; Herath \& Shamila, 2018). Thus, these findings are consistent, support and confirm the results of previous studies that personality has a positive and significant direct effect on organizational commitment with the setting of the teachers of state vocational high schools in Bogor City, West Java, Indonesia.

\subsection{Direct Effect of Reward on Job Satisfaction}

The results of this study also show that reward had a positive and significant direct effect on job satisfaction. This gives an indication that the high and low job satisfaction of teachers can be influenced by the good or bad system of reward that is applied in schools. If the reward system implemented fulfills teacher expectations, then it can contribute significantly to the realization of teacher's job satisfaction. In the reality of the dynamics of organizational life, reward is really needed by every member of the organization. Reward is not only useful for members of the organization to fulfill basic needs, but also needed to realize other needs. This is possible because reward has a broad scope that is not only limited in financial terms, but also in non-financial terms. McKenna (2006) emphasized that the reward system includes various organizational activities aimed at allocating compensation and benefits to employees in return for efforts and contributions made to achieve organizational goals. Extrinsic rewards in the form of pay, fringe benefits, and incentives can increase a person's satisfaction at work. Likewise, intrinsic rewards such as feelings of competence, accomplishment, responsibility, and personal growth are useful for satisfying psychological needs, such as self-esteem need, social need and actualization need. Rewards in the form of giving responsibility and personal growth although not physically visible, its existence is very meaningful to the teachers, because the teachers will feel that they are recognized by their existence and have a contribution to the progress of the organization. This finding is appropriate and confirms the results of previous studies conducted by Jehanzeb et al (2012), Munap, Badrillah and Rahman (2013), Bustamama, Tenga and Abdullahb (2014), and Akafo and Boateng (2015) shows that reward have an effect on job satisfaction. Thus, these findings are consistent, support and confirm the results of previous studies that reward has a positive and significant direct effect on job satisfaction with the setting of the teachers of state vocational high schools in Bogor City, West Java, Indonesia.

\subsection{Direct Effect of Personality on Job Satisfaction}

The results of this study also indicate that personality has a positive and significant direct effect on job satisfaction. This finding illustrates that the bad personality of the teacher will have an impact on the high and low level of teacher satisfaction at work. For teachers, the use of psychological (non-physical) aspects such as mind and mental are more dominant when compared to physical aspects. Personality is manifested not only in the form of physical actions, but also in psychological form. As stated by Passer and Smith (2007), personality is a way of thinking, feeling and acting that is different and lasts relatively long which characterizes a person's response to a life situation. Teacher's personality qualities reflected in conscientiousness, extraversion, agreeableness, neuroticism, and openness to experience can encourage the emergence of positive attitudes towards work, promotion, supervision, partners, leadership, working conditions, challenges, work and communication that take place in a work environment simulate the emergence of job satisfaction. This finding aligns and confirms previous research conducted by Naz, Rehman and Saqib (2013), Balasuriya and Perera (2016), Ranasinghe and Kottawatta (2016), Bui (2017), Ardakani, Heidari and Sefidgaran (2017) and shows that personality has an effect on job satisfaction. Thus, these findings are consistent, support and confirm the results of previous studies that personality has a positive and significant direct effect on job satisfaction with the setting of the teachers of state vocational high schools in Bogor City, West Java, Indonesia.

\subsection{Indirect Effect of Reward on Organizational Commitment with Job Satisfaction Mediation}

The results of this study also found that the reward had a positive and significant indirect effect on organizational commitment by mediating job satisfaction. This shows that the reward given by the school organization reflect extrinsic and intrinsic aspects (pay, fringe benefits, incentive, protection programs, feelings of competence, accomplishment, responsibility, and personal growth) pleasure the teacher so that they are satisfied with the reward, then the feeling of satisfaction will provide strength to the teacher in identifying their involvement in the organization which includes aspects: a support of acceptance of the organization's goals and values; a willingness to exert consideracle effort on behalf of the organization; and a desire to remain with the organization (being part of the organization). This result is consistent with the results of testing the other two previous hypotheses and inline by aligning and confirming the results of previous studies which prove that reward has a direct 
effect on job satisfaction (e.g: Jehanzeb et al. (2012), Munap, Badrillah and Rahman (2013), Bustamama, Tenga and Abdullahb (2014), and Akafo and Boateng (2015) and job satisfaction has a direct effect on organizational commitment (e.g. Nwokolo \& Anyamene, 2015; Tefera \& Burichew, 2016; Talasaz, Saadoldin \& Shakeri, 2017; Culibrk et al., 2018; Yao, Qiu, $\&$ Wei, 2019). Thus, these findings are consistent, support and confirm the results of previous studies that reward has a positive and significant indirect effect on organizational commitment by mediating job satisfaction with the setting of the teachers of state vocational high schools in Bogor City, West Java, Indonesia.

\subsection{Indirect Effect of Personality on Organizational Commitment with Job Satisfaction Mediation}

The results of this study have also proven that personality has a positive and significant indirect effect on organizational commitment by mediating job satisfaction. This shows that when the teacher's personality is manifested in extraversion, agreeableness, conscientiousness, neuroticism, and openness to experience in a stable condition, it can stimulate teacher's satisfaction with their work thus providing the power to identify their involvement in the organization which includes aspects: a support of acceptance of the organization's goals and values; a willingness to exert consideracle effort on behalf of the organization; and a desire to remain with the organization (being part of the organization). This result is consistent with the results of testing two other previous hypotheses and is in line with the results of previous studies which prove that personality has a direct effect on job satisfaction (e.g: Naz, Rehman and Saqib (2013), Balasuriya and Perera (2016), Ranasinghe and Kottawatta (2016), Bui (2017), Ardakani, Heidari and Sefidgaran (2017) and job satisfaction has a direct effect on organizational commitment (e.g: Nwokolo \& Anyamene, 2015; Tefera \& Burichew, 2016; Talasaz, Saadoldin \& Shakeri, 2017; Ćulibrk et al., 2018; Yao, Qiu, \& Wei, 2019). Thus, these findings are consistent, support and confirm the results of previous studies that personality has a positive and significant indirect effect on organizational commitment by mediating job satisfaction with the setting of the teachers of state vocational high schools in Bogor City, West Java, Indonesia. In addition, this study also produced a research model that was fit about the effect of reward and personality on organizational commitment by mediating job satisfaction with research settings on vocational high school in Indonesia, especially in Bogor City, West Java. This model even though it cannot be generalized in other regions in Indonesia and other countries, can be used as a measurement model of organizational commitment seen from the factors of reward and personality by mediating job satisfaction. With these conditions, the results of this study can provide important implications for researchers and practitioners. For researchers, the model produced from this study can be used as a conceptual model of research based on the measurement dimensions of the variables used in this study. For education practitioners, the model produced by this study can be used as a reference in increasing teacher organizational commitment through strengthening reward (pay, fringe benefits, incentives, protection programs, feelings of competence, accomplishment, responsibility, and personal growth), personality (extraversion, agreeableness, conscientiousness, neuroticism, and openness to experience), and job satisfaction (work itself, promotion, supervision, partners, leadership, working conditions, challenges, nature of work, and communication). However, the results of this study have a number of limitations, including: the sample is relatively limited and does not reach all cities/districts in Indonesia, the measurement dimensions of variables do not reach all dimensions available in various literatures.

\section{Conclusion}

This research proves that reward, personality and job satisfaction had direct effects on organizational commitment; reward and personality had a direct effect on job satisfaction; reward and personality had an indirect effect on organizational commitment by mediating job satisfaction, therefore a fit research model found about the effect of reward and personality on organizational commitment by mediating job satisfaction with research settings on vocational high school in Indonesia. This model cannot only be used as a reference by researchers and practitioners in developing models of organizational commitment that are in accordance with their respective conditions, but can also be further developed and expanded into studies and projects to develop organizational commitment that is more complex and comprehensive by adding variables and other relevant dimensions.

\section{References}

Abebe, T., \& Markos, S. (2016). The relationship between job satisfaction and organizational commitment in public higher education institution: the case of Arba Minch university, Ethiopia. IMPACT: International Journal of Research in Business Management (IMPACT: IJRBM), 4(8), 17-36.

Akafo, V., \& Boateng, P. A. (2015). Impact of reward and recognition on job satisfaction and motivation. European Journal of Business and Management, 7(24), 112-124.

Ardakani, H. M., Heidari, S., \& Sefidgaran, B. (2017). The study of relationship between personality traits and job satisfaction in Iran Khodro Company experts in Iran. EUROPEAN PSYCHIATRY The Journal of The European Psychiatry Association, 41, 714-715.

Balasuriya, B. L. L. A., \& Perera, G. D. N. (2016). The impact of personality on job satisfaction: a study of executive employees in selected private hospitals in Colombo East, Sri Lanka. IJRDO-Journal of Business Management, 2(12), 6-15.

Bangwal, D., Tiwari, P., \& Chamola, P. (2017). Workplace design features, job satisfaction, and organization commitment. SAGE Open Journal of workplace rights, 1-12.

Bui, H. (2017). Big five personality traits and job satisfaction: evidence from a national sample. Journal of General Management, 42(3), 21-30.

Bustamama, F. L., Tenga, S. S., \& Abdullah, F. Z. (2014). Reward management and job satisfaction among frontline employees in hotel industry in Malaysia. Procedia-Social and Behavioral Sciences, 144, 392-402. 
Carver, C. S., \& Scheier, M. F. (2008). Perspectives on personality. Boston: Pearson Education, Inc., 2008.

Chelangat, Z., \& Gachunga, H. (2016). Effect of reward management practices on organisational commitment in state corporations in Kenya: A case study of Kefr. The Strategic Journal of Business and Change Management, 3(3), 325-346.

Ciccarelli, S. K., \& Meyer, G.E. (2006). Psychology. New Jersey: Prentice Hall.

Costa, P. T., \& McCrae, R. R. (1992). The NEO-PI Personality Inventory. Odessa, FL: Psychological Assessment Resources.

Ćulibrk, J., Delić*, M., Mitrović, S., \& Ćulibrk, D. (2018). Job satisfaction, organizational commitment and job involvement: the mediating role of job involvement. Original Research Frontier in Psychology, 9, 1-12.

David, S., Gidwani, R., Birthare, N., \& Singh, P. (2015). Impacts of job satisfaction and organizational commitment: a study describing influence of gender difference on job satisfaction and organizational commitment. International Journal of Core Engineering \& Management (IJCEM), 2(1), 93-111.

Faridi, A., Baloch, A., \& Wajidi, A. (2017). The mediating role of job satisfaction between training and development practices and organizational commitment: responses from private banking sectors of Karachi, Pakistan. International Journal of Academic Research in Business and Social Sciences, 7(10), 603-616.

Getahun, T., Tefera, B. F., \& Burichew, A. H. (2016). Teacher's job satisfaction and its relationship with organizational commitment in Ethiopian primary schools: focus on primary schools of Bonga town. European Scientific Journal May, 12(13), 380-401.

Herath, H. M. M. L., \& Shamila, F. A. (2018). The impact of employee personality traits on organizational commitment in an apparel industry in trincomalee district. SAJSSE South Asian Journal of Social Studies and Economics, 1(1), 1-11.

Jehanzeb, K., Rasheed, M. F., Rasheed, A., \& Aamir, A. (2012). Impact of rewards and motivation on job satisfaction in banking sector of Saudi Arabia. International Journal of Business and Social Science, 3(21), 272-278.

Korir, I., \& Kipkebut, D. (2016). The effect of reward management on employees commitment in the universities in Nakuru County-Kenya. Journal of Human Resource Management, 4(4), 37-48.

Kreitner, R., \& Kinicki, A. (2010). Organizatioan behavior, $9^{\text {th }}$ edition. New York: M cGraw-Hill Irwin.

Krejcie, R.V., \& Morgan, D.W. (1970). Determining sample size for research activities. Educational and Psychological Measurement, 1970, 30, 607-610.

Luthans, F. (2011). Orgnazational Behavior, $11^{\text {th }}$ edition. Boston: McGraw-Hill.

Mabaso, C. M., \& Dlamini, B. I. (2018). Total rewards and its effects on organizational commitment in higher education institutions. SA Journal of Human Resource Management/SA Tydskrif vir Menslikehulpbronbestuur, 16(0), 913, 1-8.

Martocchio, J.J. (2004). Strategic compensation. New Jersey: Pearson Education Inc.

McKenna, E. (2006). Business and psychology: organizational behavior. New York: Psychology Press.

Munap, R., Badrillah, M. I. M., \& Rahman, B. A. (2013). Organizational rewards system and employees' satisfaction at telekom Malaysia Berhad. Journal of Educational and Social Research, 3(3), 281-288.

Naz, S., Rehman, S., \& Saqib, H. (2013). The relationship between job satisfaction and personality trait among bank employees. Far East Journal of Psychology and Business, 11(3), 57-72.

Newstrom, J. W. (2015). Organization behavior: human behavior at work, $12^{\text {th }}$ edition. Boston: McGraw Hill.

Nwokolo, C., \& Anyamene, A. (2015). Relationship between job satisfaction and commitment among secondary school counsellors in Anambra State, Nigeria. European Journal of Education Studies, 103-114.

Passer, M.W., \& Smith, R.E. (2007). Psychology: the science of mind and behavior. New York: McGraw-Hill.

Ranasinghe, V. R., \& Kottawatta, H. K. (2016). Big five personality on job satisfaction: perspective of Sri Lankan male and female school teachers. Imperial Journal of Interdisciplinary Research (IJIR), 2(12), 825-835.

Santrock, J.S. (2008). Educational psychology. New York: McGraw-Hill.

Saqib, S., Abrar, M., Sabir, H. M., Bashir, M., \& Baig, S. A. (2015). Impact of tangible and intangible rewards on organizational commitment: evidence from the textile sector of Pakistan. American Journal of Industrial and Business Management, 5(3), 138-147.

Saufi, R. A., Xin, Y., Hongyun, C., Berhan, S. A., \& Al Mamun, A. (2017). The relationship between personality dimensions and employee job commitment in private higher learning institutions. International Review of Management and Marketing, 7(1), 428-432.

Shabahang, M. J., \& Amani, M. (2016). The relationship between personality factors and organizational commitment of Iranian primary school principals. International Journal of Psychology and Educational Studies, 3(3), 50-59.

Spector, P.E. (1997). Job satisfaction. California: SAGE Publishing.

Slocum, J.W., \& Hellrigel, D. (2007). Fundamental of organizational behavior. Mason, USA: Thomson Hihger Education.

Talasaz, Z. H., Saadoldin, S. N., \& Shakeri, M. T. (2017). Job satisfaction and occupational stress in organizational commitment among midwives working in the maternity wards; Mashhad, Iran, 2014. Health Scope, 6,(1):e35507

Vecchio, R. P. (2006). Organizational behavior. United State: Thomson South-Western.

Wang, J. H., Tsai, K. C., Lei, L. J. R., Chio, I. F., \& Lai, S. K. (2016). Relationships among job satisfaction, organizational commitment, and turnover intention: evidence from the gambling industry in Macau. Business and Management Studies, 2(1), 104-110.

Yao, T., Qiu, Q., \& Wei, Y. (2019). Retaining hotel employees as internal customers: Effect of organizational commitment on attitudinal and behavioral loyalty of employees. International Journal of Hospitality Management, 76(Part A), 1-8.

Yongmei, X., \& Jiankai, J. (2015). Empirical research on relationship of caddies' reward satisfaction, organizational commitment and turnover intention. Chinese Studies, 4, 56-63.

Ziapour, A., Khatony, A., Jafari, F., \& Kianipour, N. (2017). Correlation between personality traits and organizational commitment in the staff of Kermanshah University of Medical Sciences in 2015. AHRO Annals of Tropical Medicine and Public Health, 10(2), 371-376.

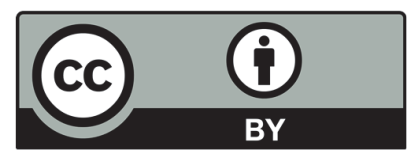

(C) 2020 by the authors; licensee Growing Science, Canada. This is an open access article distributed under the terms and conditions of the Creative Commons Attribution (CC-BY) license (http://creativecommons.org/licenses/by/4.0/). 